\title{
Preclinical and Clinical Developments in Molecular Targeting Therapeutic Strategies for Breast Cancer
}

\author{
Teruhiko Fujii1 ${ }^{1,2,3}$, Hiroki Takahashi1,2, Yuka Inoue ${ }^{1}$, \\ Masayoshi Kage ${ }^{3,4}$, Hideaki Yamana ${ }^{5}$ and Kazuo Shirouzu ${ }^{2}$ \\ ${ }^{1}$ Breast Care Center, Clinical Research Institute, \\ National Hospital Organization Kyushu Medical Cancer, \\ ${ }^{2}$ Department of Surgery, Kurume University, Japan \\ ${ }^{3}$ Center for Innovative Cancer Therapy, Kurume University, \\ ${ }^{4}$ Department of Pathology, Kurume University, \\ ${ }_{5}^{5}$ Multidisciplinary Treatment Center, Kurume University, \\ Japan
}

\section{Introduction}

The development of effective chemotherapy has greatly improved survival among patients with breast cancer, although molecular cancer therapeutics is also emerging as an important approach. Molecular-targeting therapy using agents such as trastuzumab has enhanced breast cancer treatment, while clinical trials have suggested that epidermal growth factor receptor (EGFR), vascular endothelial growth factor (VEGF), and mammalian target of rapamycin (mTOR) are potential targets. Our current efforts to identify molecular targets that might be useful for treatment are focused on two molecules: the putative metastasissuppressor gene Cap43/NDRG1/Drg-1 (Cap43) protein and the Y-box binding protein-1 (YB-1). Here we describe the latest preclinical and clinical developments in moleculartargeting therapeutic strategies for breast cancer, including those using Cap43 and YB-1.

\section{Current study of molecular-targeting agents}

\subsection{EGFR family signaling}

The EGFR family of receptor tyrosine kinases is an attractive target for anticancer strategies. Members include EGFR, which is also known as human epidermal growth factor receptor 1 (HER1), HER2 (erbB2), HER3 (erbB3), and HER4 (erbB4). Through their interconnected cellular signaling network, EGFR family members regulate diverse biological processes including cell proliferation, differentiation, and survival. They also play key roles in the development and progression of breast cancer. High levels of EGFR and HER2 expression have been reported in 15-30\% of breast cancers, and are correlated with poor prognosis ( Schlotter et al., 2008; Witton et al., 2003). HER3 expression, observed in $18 \%$ of tumors, is correlated with reduced overall survival (OS) and it may provide a rout for resistance to agents targeting EGFE or HER2 (Koutras et al., 2010; Witton et al., 2003). By contrast, HER4 
expression, observed in $12 \%$ of tumors, is associated with differentiation and growth inhibition, thus it is more consistently related with favorable prognosis in breast cancer (Koutras et al., 2010; Witton et al., 2003). EGFRs have an extracellular domain involved in ligand binding, a helical transmembrane segment, and an intracellular protein kinase domain. Upon ligand binding, the extracellular domain undergoes conformational changes that allow EGFR family members to form homodimers or heterodimers. Particularly, the combination of HER2 and HER3 receptors may be critical in breast cancer growth and progression. Ligand binding induces dimerization of the receptor and activation of the kinase through autophosphorylation, stimulating phosphoinositide 3-kinase (PI3K)/Akt and mitogen-activated protein kinase (MAPK) signaling. This is followed by proliferation, migration, adhesion, and angiogenesis (Atalay et al., 2003; Lin \& Winer, 2004; Rosen et al., 2010; Russo \& Ove, 2003; Schlotter, 2008).

\subsection{EGFR family-targeted therapies}

\subsubsection{Trastuzumab}

Targeting signaling has led to the development of therapies that reduce the activation of HER2 in breast cancer. Trastuzumab is a humanized monoclonal antibody that targets the extracellular domain of the transmembrane tyrosine kinase HER2, and is a key drug in the treatment strategy for HER2-positive breast cancer. National Comprehensive Cancer Network (NCCN) guidelines recommend both trastuzumab monotherapy and combined trastuzumab and chemotherapy as first-line treatments for metastatic breast cancer (MBC) (NCCN 2011), and these have both shown efficacy in HER2-positive MBC patients (Slamon et al., 2001; Vogel et al., 2002). Data from the National Surgical Adjuvant Breast and Bowel Project (NSABP) B-31 + North Central Cancer Treatment Group (NCCTG) N9831 trial, the HERceptin Adjuvant (HERA) trial, the Breast Cancer International Research Group (BCIRG) 006 trial, and the Finland Herceptin (FinHer) trial (Joensuu et al., 2006; Perez et al., 2007; Slamon et al., 2006; Smith et al., 2007) have suggested that adjuvant trastuzumab treatment improves both disease-free survival (DFS) and OS among early breast cancer patients. NCCN guidelines and the St Gallen consensus guidelines therefore recommend that adjuvant trastuzumab treatment should be used for node-positive and node-negative, highrisk early HER2-positive breast cancer patients (NCCN 2011; Goldhirsch et al., 2009). The efficacy of adjuvant trastuzumab therapy for HER2-positive breast cancer patients with a tumor size of less than $1 \mathrm{~cm}$ is unclear. Gonzalez-Angulo et al. reported that such patients who were HER2-positive had higher risks of recurrence and distant recurrence than those who were HER2-negative. These results suggest that patients with HER2-positive T1abN0M0 tumors have a significant risk of relapse and should be considered for trastuzumab adjuvant therapy (Gonzalez-Angulo et al., 2009). A retrospective analysis of the effect of adjuvant trastuzumab in patients with small, node-negative, HER2-positive breast cancer was reported at the 2010 American Society of Clinical Oncology (ASCO) meeting. This concluded that even small breast cancers probably derive significant benefit from adjuvant trastuzumab therapy (McArthur et al., 2010). The NeOAdjuvant Herceptin (NOAH) trial (Gianni et al., 2010a) was a randomized study that evaluated the addition of trastuzumab to anthracycline- and taxane-based chemotherapy for patients with HER2positive locally advanced breast cancer in a neoadjuvant setting. Trastuzumab was well tolerated, and significantly improved the 3-year event-free survival (EFS) of patients with HER2-positive breast cancer ( $71 \%$ with trastuzumab vs $56 \%$ without trastuzumab, $p=0.013$ ). The addition of trastuzumab to neoadjuvant chemotherapy should therefore be considered 
for women with HER2-positive, locally advanced or inflammatory breast cancer in order to improve the EFS, survival, and clinical and pathological tumor responses.

\subsubsection{Trastuzumab-DM1 (T-DM1)}

T-DM1 is an antibody-drug conjugate that uses trastuzumab to deliver the maytansinoid antimicrotubule agent DM1 specifically to HER2-positive cells. T-DM1 was previously shown to be well tolerated with no dose-limiting cardiotoxicity, with an objective response rate by independent assessment of $25.9 \%$, and a median progression-free survival (PFS) time of 4.6 months (Burris et al., 2011). These results suggest that T-DM1 monotherapy is useful in patients with heavily pretreated, HER2-positive MBC.

\subsubsection{Pertuzumab}

HER2-containing heterodimers elicit greater mitogenic responses than HER2 homodimers. The ligand-induced activation of either HER1 or HER3, and the subsequent formation of heterodimers with HER2, might therefore play an important role in resistance to conventional HER2 inhibitors. Pertuzumab is a humanized monoclonal antibody and a member of a new class of inhibitors, including EGFR family members such as HER3, that block HER2 dimerization, thereby inhibiting the downstream signaling processes associated with tumor growth and progression (Adams et al., 2006; Franklin et al., 2004). Clinical studies have indicated that pertuzumab monotherapy shows limited efficacy for HER2positive or HER2-negative advanced breast cancer (Cortes et al., 2009; Gianni et al., 2010b). Trastuzumab and pertuzumab bind to distinct epitopes on the HER2 extracellular domain, and it has been hypothesized that a combination of the two agents might inhibit tumor growth more effectively than either agent alone (Franklin et al., 2004; Hubbard, 2005). Indeed, in vivo data showed that the combination had a strongly enhanced antitumor effect and induced tumor regression in breast cancer xenograft models, which was not achieved by either agent alone (Scheuer et al., 2009). In view of this synergistic effect, a phase II trial of pertuzumab and trastuzumab combination therapy in patients with HER2-positive MBC was performed. The objective response rate (ORR) was $24.2 \%$ and the clinical benefit rate (CBR) $50 \%$. The combination was active and well tolerated in patients who had experienced progression during previous trastuzumab therapy (Baselga et al., 2010a). A phase Ib/II trial of T-DM1 with pertuzumab combination therapy for locally advanced or MBC was also reported, and nine partial responses (PRs) were observed among 23 patients (Miller et al., 2010). Due to the safety, tolerability, and efficacy of full-dose T-DM1 plus pertuzumab, this approach is a promising new treatment strategy for MBC. In addition, the ongoing, randomized, phase II Pertuzumab HERceptin Evaluation with XelodA (PHEREXA) study will evaluate the efficacy and safety of a combination of trastuzumab and capecitabine with or without pertuzumab in patients with HER2-positive MBC (ClinicalTrials.gov 1). Pertuzumab and trastuzumab combination therapy was also investigated in The Neoadjuvant Study of Pertuzumab and Herceptin in an Early Regimen Evaluation (NeoSphere) trial, which was a phase II clinical study of preoperative systemic therapy that ranked the antitumor activity and tolerability of the following combinations: trastuzumab+docetaxel, docetaxel+trastuzumab+pertuzumab, trastuzumab+pertuzumab, and docetaxel+pertuzumab. The clinical CR+PR rates were $80 \%, 88 \%, 68 \%$, and $71 \%$, respectively, while pathologic complete response (pCR) rates were $29 \%, 45.8 \%, 17.8 \%$, and $24 \%$, respectively (Gianni et al., 2010c). These data showed superior antitumor activity in the 
docetaxel+trastuzumab+pertuzumab group. Notably, the trastuzumab+pertuzumab group also showed excellent tolerability and effective antitumor activity, which is expected to lead to the establishment of molecular-targeting therapy that does not involve toxic chemotherapy.

\subsection{Tyrosine kinase inhibitors}

\subsubsection{Lapatinib}

Lapatinib is an oral small-molecule tyrosine kinase inhibitor that reversibly inhibits both EGFR and HER2 (Lackey, 2006). Binding of EGFR ligands to EGFR stimulates heterodimerization with HER2 and activation of downstream signaling pathways including PI3K, Akt protein kinase, and mTOR, resulting in an increase in cell proliferation. Phosphatase and tensin homolog (PTEN) has tumor-suppressor activity in this signaling pathway, and loss of PTEN, as well as up-regulation of insulin-like growth factor 1 receptor (IGF-1R) signaling, is associated with trastuzumab resistance. Lapatinib blocks the activation of the HER2 signaling pathway by inhibiting the intracellular tyrosine kinase of EGFR and HER2, and Lapatinib is believed to circumvent the trastuzumab resistance associated with the up-regulation of IGF-1R signaling. Lapatinib also binds to the p95 truncated variant of HER2 (p95 HER2) and inhibits cell proliferation in trastuzumabresistant cells expressing p95 HER2. This suggests that lapatinib is a potential therapeutic for breast cancer patients who are resistant to trastuzumab (Vogel et al., 2010). In a phase II clinical trial (EGF20009), lapatinib monotherapy demonstrated clinical activity and was well tolerated as a first-line therapy in HER2-amplified locally advanced or MBC (Gomez et al., 2008). In a randomized phase III study, patients with HER2-positive MBC that had progressed after treatment with anthracycline, taxane, and trastuzumab were given combination therapy with lapatinib and capecitabine. The performance of this was superior to capecitabine alone, with no increase in serious toxic effects (Geyer et al., 2006). A phase III randomized study comparing lapatinib alone with lapatinib plus paclitaxel as first-line treatment for MBC also found that the combination therapy significantly improved clinical outcomes in HER2-positive patients (Di Leo et al., 2008). Preclinical studies have shown that lapatinib is active not only as a monotherapy but also in combination with trastuzumab (Konecny et al., 2006; Xia et al., 2002; Xia et al., 2005). A randomized phase III study (EGF104900) compared the activity of lapatinib alone and in combination with trastuzumab in patients with HER2-positive, trastuzumab-refractory MBC. The combination treatment performance was superior to lapatinib alone in terms of both the PFS and the CBR (Blackwell et al., 2010). This was also supported by the Neoadjuvant Lapatinib and/or Trastuzumab Treatment Optimization (NeoALTTO) phase III randomized neoadjuvant study which compared lapatinib and trastuzumab both alone and in combination with paclitaxel for the treatment of HER2-positive primary breast cancer. pCR rates for the three arms were $24.7 \%$ for lapatinib alone, $29.5 \%$ for trastuzumab alone, and $51.3 \%$ for the combination (Baselga et al., 2010b). These results suggested that combination therapy with lapatinib and trastuzumab is useful for both metastatic and primary breast cancers. Brain metastases are common among HER2-positive MCB patients, and usually imply poor prognosis and short survival. Because lapatinib is a small-molecule tyrosine kinase inhibitor, it might be able to cross the blood-brain barrier to provide effect therapeutic concentrations in cerebrospinal fluid. In mice with established brain metastases, treatment with lapatinib significantly suppressed the growth of brain metastases (Gril et al., 2008). In clinical trials, lapatinib monotherapy showed modest antitumor activity against brain metastases, and 
additional responses were observed for a combination of lapatinib and capecitabine (Lin et al., 2009; Metro et al., 2010; Ro et al., 2010). These data suggest that lapatinib is an effective therapeutic for brain metastases from breast cancer.

\subsubsection{Erlotinib}

Erlotinib is a highly potent reversible inhibitor of HER1/EGFR tyrosine kinase. It is activated by the extracellular binding of EGF, and is potentiated by the dimerization of activated receptors. Erlotinib has been shown to inhibit tumor cell growth in several human cancers (Moyer et al., 1997; Pollack et al., 1999). In clinical trials, erlotinib showed antitumor effects in patients with NSCLC, squamous cell carcinoma of the head and neck, and hepatocellular carcinoma (Pérez-Soler et al., 2004; Soulieres et al., 2004; Thomas et al., 2007); however, erlotinib monotherapy had minimal activity in patients with breast cancer (Dickler et al., 2009). In HER2-positive breast cancer models, the concurrent inhibition of HER2 and EGFR led to improved anticancer activity compared with the inhibition of HER2 alone. In breast cancer cell lines, trastuzumab and erlotinib demonstrated synergistic activity over a range of clinically relevant concentrations (Finn et al., 2003) and, in xenograft models, antiEGFR plus VEGF therapy showed increased activity compared with either agent alone (Jung et al., 2002). These results provided a rationale for combining trastuzumab or bevacizumab with erlotinib in clinical studies. The combination of erlotinib and trastuzumab has been found to be well tolerated, with four PRs achieved in 12 patients, and a time to progression (TTP) of 9.03 months (Britten et al., 2009). The combination of erlotinib and bevacizumab was examined in 38 patients with MBC, one of whom achieved a PR, 15 had stable disease at first evaluation (at 9 weeks), and four of these had stable disease (SD) beyond 26 weeks. Although this combination therapy was well tolerated, it showed limited activity in unselected patients with previously treated MBC (Dickler et al., 2008). Current clinical trials are investigating the use of combination therapy with erlotinib and oral mTOR protein kinase inhibitor (Everolimus) (ClinicalTrials.gov 2), hormone therapy (fulvestrant) (ClinicalTrials.gov 3), and chemotherapy (docetaxel) (ClinicalTrials.gov 4) for breast cancer.

\subsubsection{Gefitinib}

Gefitinib is a small-molecule anticancer agent. This selective EGFR tyrosine kinase inhibitor blocks the signal-transduction pathway implicated in the proliferation and survival of cancer cells (Albanell et al., 2002; Woodburn, 1999). Preclinical studies clearly established that gefitinib potently inhibits growth in various human cancer cells (Ciardiello et al., 2000; Sirotnak et al., 2000; Wakeling et al., 2002), and similar growth-inhibitory effects of gefitinib have been reported in breast cancer models (Campiglio et al., 2004; Lu et al., 2003; Moulder et al., 2001). A significant antitumor effect was observed in the Iressa Dose Evaluation in Advanced Lung Cancer (IDEAL) clinical trial, and gefitinib is now approved in several countries for the treatment of advanced NSCLC (Bell et al., 2005; Fukuoka, 2003). However, clinical trials showed that gefitinib monotherapy did not appear to be efficacious in the treatment of advanced MBC patients (von Minckwitz et al 2005). A phase II clinical trial found that gefitinib in combination with docetaxel was an active regimen for patients with MBC (Dennison et al., 2007). Phase II clinical trials of gefitinib in combination with either the non-steroidal aromatase inhibitor anastrozole or tamoxifen showed improved PFS (Cristofanilli et al., 2010; Osborne et al., 2011). Although combined treatment with drugs that target EGFR (gefitinib) and HER2 (trastuzumab) resulted in efficient inhibition of tumor growth in breast cancer cells that co-expressed both receptors (Normanno et al., 2002), a 
phase I/II study showed that gefitinib in combination with trastuzumab was unlikely to result in clinical benefit compared with trastuzumab alone (Arteaga et al., 2008). Further investigation is warranted to clarify the effect of gefitinib in breast cancer patients.

\section{4 mTOR inhibitors}

PTEN exhibits tumor suppressor activity in the PI3K/Akt/mTOR signaling pathway, and its loss is associated with trastuzumab resistance. Everolimus (RAD001) is a rapamycin ester analog that inhibits $\mathrm{mTOR}$, and in combination with trastuzumab, it has been reported to inhibit breast cancer growth in vitro and in vivo (Lu et al., 2007). These results strongly suggested promising results of the concomitant use of trastuzumab with mTOR inhibitor for treating cases of trastuzumab resistance by PTEN loss. A randomized phase II study evaluated patients with $\mathrm{MBC}$ and reported that their response rate with daily everolimus monotherapy was $12 \%$ (Ellard et al., 2009). Everolimus has also been studied in combination with chemotherapy. Combination therapy of everolimus with paclitaxel and trastuzumab in patients with HER2-overexpressing MBC pretreated with trastuzumab has been reported. The ORR of this therapy was $44 \%$ and it was generally well tolerated. When combined with vinorelbine and trastuzumab, everolimus exhibited an ORR of $19.1 \%$, with a disease control rate of $83.0 \%$ and a median PFS of 30.7 weeks (Jerusalem et al., 2011). These clinical data suggested that everolimus combined with chemotherapy and trastuzumab is generally well tolerated and exhibits promising antitumor activity in heavily pretreated patients with HER2-overexpressing MBC that progressed on trastuzumab therapy. A summary of EGFR family signaling and target therapies for breast cancer is presented in Fig. 1.

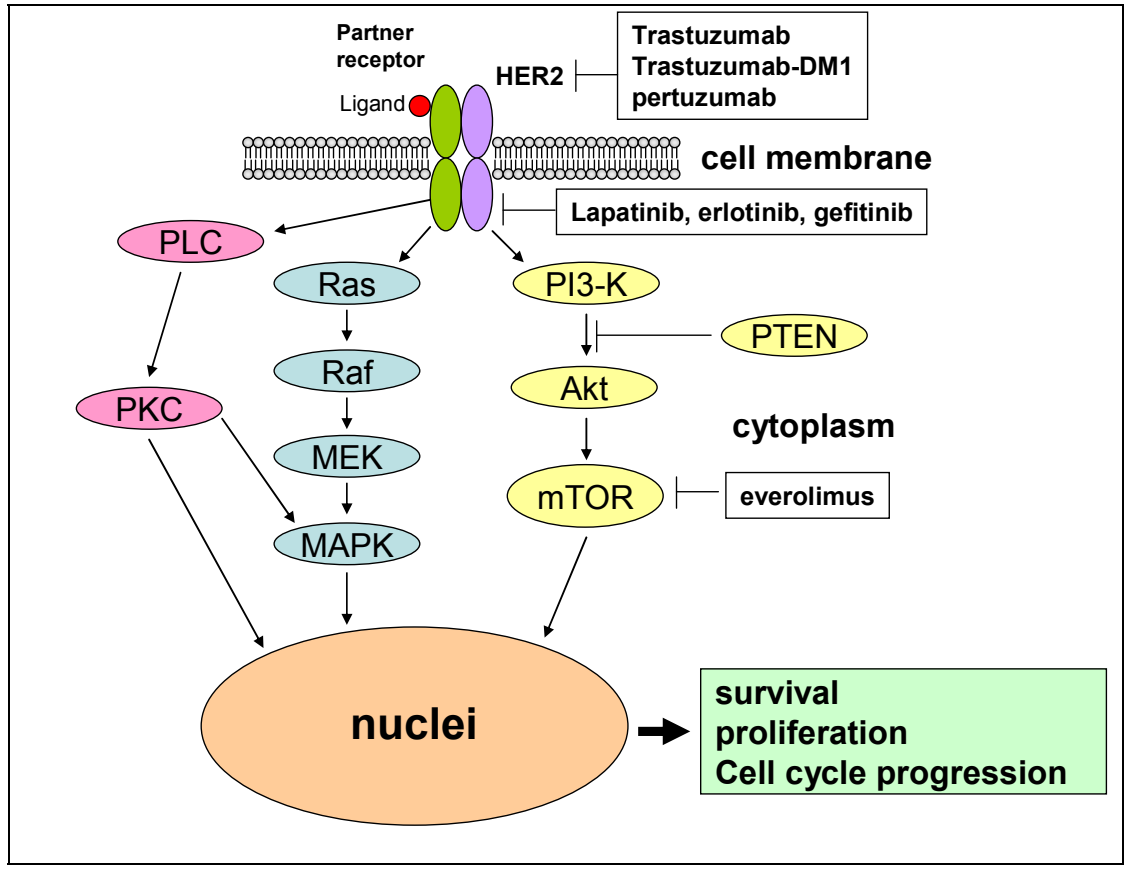

Fig. 1. EGFR family signaling and target therapies for breast cancer 


\subsection{Angiogenesis pathway}

Angiogenesis is essential for tumor growth or metastasis. The primary factor controlling vessel formation is hypoxia, which triggers the secretion of pro-angiogenic factors, particularly VEGF, and stimulates new vessel formation to supply oxygen to the tumor. VEGF therefore plays a key role in tumor angiogenesis (Ferrara et al., 2003; Jain, 2003; Yancopoulos et al., 2000). It is a 34-46 KDa homodimeric glycoprotein that acts as a ligand for Flt-1 (VEGF receptor-1 or VEGFR-1) and KDR or Flt-2 (VEGFR-2). Under hypoxic conditions, the transcription factors hypoxia-inducible factor-1 alpha (HIF-1 alpha ) and HIF-2 alpha are stabilized in cancer cells, then transported to the nucleus where they interact with HIF-beta. This complex binds to a specific sequence on the VEGF gene called the hypoxia response element (HRE), which stimulates VEGF gene transcription; VEGF protein is produced and then secreted from cancer cells (Fox et al., 2007; Shibuya, 2001). VEGF binds to VEGFR-2, which is expressed on the endothelial cell membrane, and homodimerization of the latter occurs. The effects of VEGF are mediated by the activation of various intracellular signaling transduction pathways, such as receptor tyrosine kinase activity or autophosphorylation of VEGFR-2, and the receptor mediates the biological action via the phospholipase C (PLC)-protein kinase C (PKC)-MAPK pathway. In other words, PLC directly binds to the autophosphorylated VEGFR-2, is tyrosine-phosphorylated then activated; this stimulates the activation of PKC and the Raf-1-MAPK cascade (Shibuya, 2001; Takahashi et al., 1999). Several preclinical studies showed that a VEGF-specific monoclonal antibody suppressed neovascularization and inhibited tumor growth arising from human cancer cell lines injected into nude mice (Fox et al., 2002; Kim et al., 1993). These results strongly suggest that VEGF inhibition blocks angiogenesis and tumor growth. The mechanism of the antitumor effect achieved through targeting VEGF might involve the stimulation of apoptosis of the tumor vasculature, the inhibition of metastasis, or the initiation of antitumor immune responses. VEGF inhibition might prevent its protective effect against apoptosis in tumor blood vessel-associated endothelial cells, leading to disruption of the tumor blood supply. In view of this antitumor activity, drugs targeting the VEGF system are currently in development. Mechanism of VEGF signaling is illustrated in figure 2 .

\subsubsection{Bevacizumab}

The most promising approaches are offered by monoclonal antibodies directed against VEGF. Among the drugs in this class, bevacizumab, which consists of $93 \%$ human and $7 \%$ murine components, is currently at the most advanced stage of development. Bevacizumab is highly specific to VEGF-A and prevents angiogenesis by inhibiting the VEGF ligand thereby inhibiting VEGF signaling. Bevacizumab potently reduced the growth rate of several malignant tumors using xenograft models (Lee et al., 2008; Segerström et al., 2006) but, in a phase I/II trial, the clinical effects of bevacizumab monotherapy for breast cancer were unclear (Cobleigh et al., 2003); these might, however, be enhanced by using a combination of conventional chemotherapy and bevacizumab. The randomized phase III Eastern Cooperative Oncology Group 2100 (ECOG-E2100) trial compared paclitaxel with or without bevacizumab as first-line therapy for HER2-negative MBC; the addition of bevacizumab significantly increased the ORR $(36.9 \%$ vs $21.2 \% ; p<0.001)$ and the PFS $(11.8$ vs 5.9 months; $p<0.001$ ), but not the OS (26.7 vs 25.2 months; $p=0.16$ ) (Miller et al., 2007). Nevertheless, first-line anti-angiogenic therapy using bevacizumab clearly improved the response for earlier stage MBC. The Avastin and Docetaxel (AVADO) trial compared 


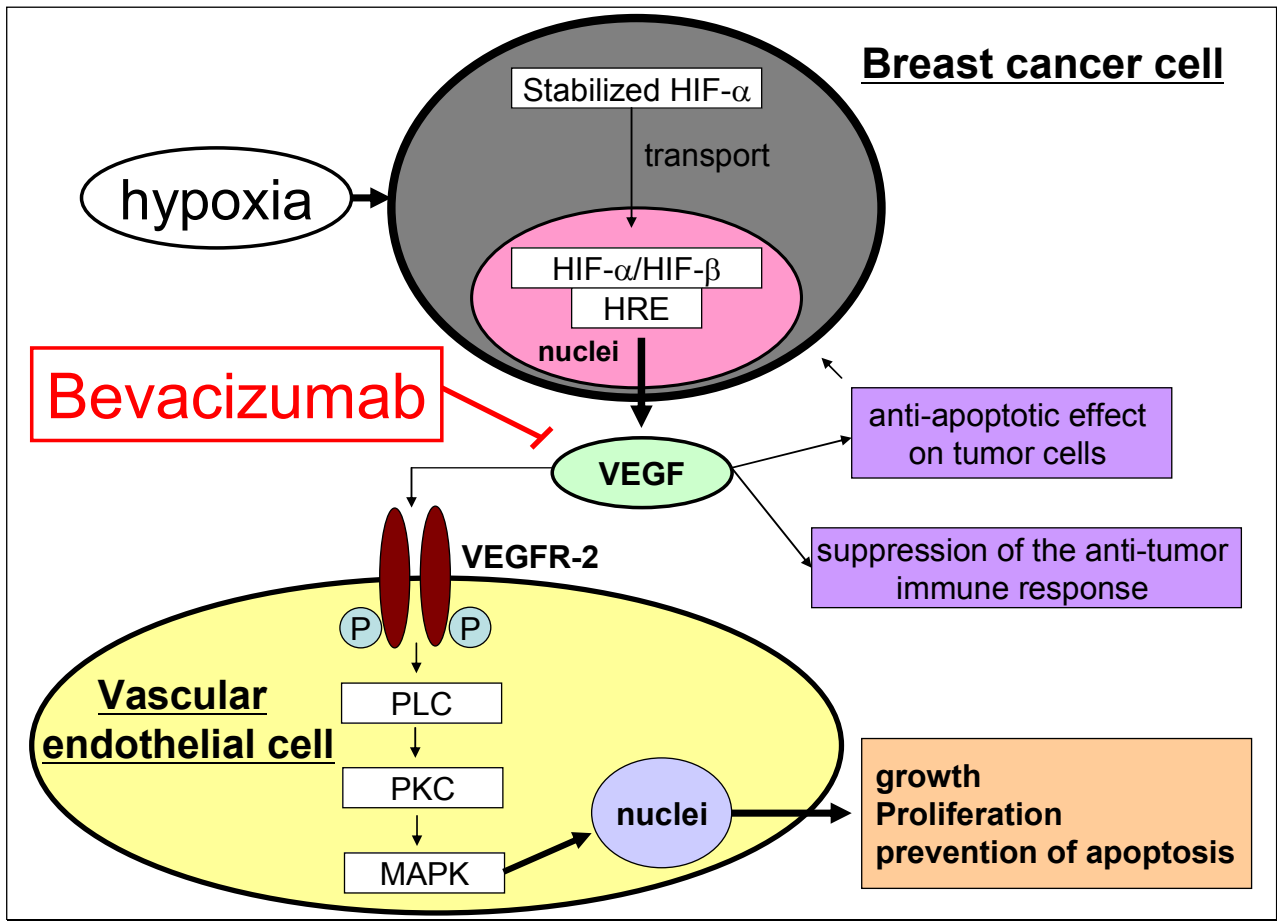

Fig. 2. Mechanisum of VEGF signaling

docetaxel with or without bevacizumab (at $7.5 \mathrm{mg} / \mathrm{kg}$ or $15 \mathrm{mg} / \mathrm{kg}$ ) as first-line therapy for HER2-negative MBC (Miles et al., 2009). The combination therapy significantly increased the PFS (8.2 months for docetaxel plus placebo, 9.0 months for docetaxel plus bevacizumab at $7.5 \mathrm{mg} / \mathrm{kg}$, and 10.1 months for docetaxel plus bevacizumab at $15 \mathrm{mg} / \mathrm{kg})$, overall RR (46\%, $55 \%$, and $64 \%$, respectively) and 1-year survival rates (76\%, $81 \%$, and $84 \%$, respectively). As described above, a stronger antitumor effect is expected when prescribing bevacizumab to patients at an earlier stage of MBC. Several first or second-line clinical trials using bevacizumab are currently ongoing. The Regimens in Bevacizumab for Breast Oncology (RiBBON 1) trial is a phase III study that aims to establish standard first-line chemotherapy regimens and is comparing paclitaxel with or without bevacizumab for 722 HER2-negative MBC patients, while the RiBBON 2 trial is investigating second-line therapy. In addition, chemotherapy (an anthracycline-based regimen, taxane, or capecitabine) plus bevacizumab is being compared with chemotherapy plus placebo; the estimated enrollment for this study is 1,200 patients, and the primary endpoint is PFS (O'Shaughnessy \& Brufsky, 2008). A firstline clinical trial using bevacizumab for triple-negative breast cancer is also ongoing. Triplenegative breast cancer does not react to hormone therapy or trastuzumab, so the prognosis is poor (Sørlie et al., 2001). Chemotherapy is the only suitable current treatment, but a combination of chemotherapy and bevacizumab is expected to be effective. Phase II trials of bevacizumab in combination with other regimens are currently underway for triplenegative $\mathrm{MBC}$, these include an association with doxorubicin and carboplatin, an estimated 
enrollment of 50 patients and PFS as the primary endpoint (ClinicalTrials.gov 5), and an association with paclitaxel and carboplatin, an estimated enrollment of 46, and overall RR as the primary endpoint (ClinicalTrials.gov 6). If a stronger antitumor effect is shown by these clinical trials, it will suggest that bevacizumab is a good treatment strategy for triplenegative breast cancer. A first-line clinical trial of bevacizumab combined with other molecular targeting therapy is also ongoing. HER2 plays a specific role in the regulation of VEGF expression. A preclinical study showed a strong association between HER2 and VEGF (Klos et al., 2006; Konecny et al., 2004), while animal models showed superior efficacy when bevacizumab was combined with trastuzumab (Scheuer et al., 2006). Based on these results, a phase II trial of combined therapy targeting HER2-amplified MBC or local relapse, and surgically-unresectable breast cancer, was carried out using trastuzumab and bevacizumab as first-line treatment. A clinical response was documented in 13 of 28 patients (46\%), all of whom showed a PR (Pegram 2006). These data support the clinical use of combination therapy with bevacizumab and trastuzumab, and suggest that it is an effective first-line therapy for HER2-overexpressing MBC.

The novel targeted agents that are currently being clinically evaluated for use in breast cancer are expected to show promising results. We are also continuing to investigate other molecules that might be useful for treatment of breast cancer. Our goal is to establish the potential of such agents to be translated into novel and useful approaches to breast cancer therapy, and to move promising lead compounds rapidly from the bench to the bedside. The preclinical molecular-targeting strategies that we are using against breast cancer focus on Cap43 and YB-1, as discussed below.

\section{Cap43}

Cap43 is a $43-\mathrm{kD}$ protein identical to $\mathrm{N}$-myc downstream-regulated gene 1 (NDRG1) and differentiation-related gene-1 (Drg-1). Cap43 expression is markedly influenced by several stimuli, including oxidative stress, metal ions, hypoxia, phorbol esters, vitamins A and D, and steroids, the oncogenes $\mathrm{N}$-myc and C-myc, and the tumor-suppressor genes p53 and Von Hippel-Lindau (VHL). Although many studies have elucidated the characteristics of Cap43, its exact function remains unclear. Cap43 is expressed in various organs, including the prostate, ovary, colon, and kidney, and its expression changes dynamically during postnatal development in the kidney, brain, liver, and nerves (Lachat et al., 2002; Okuda et al., 1999; Shimono et al., 1999; Wakisaka et al., 2003). These observations suggested that Cap43 may be involved in normal organ maturation and differentiation. Cap43 expression has been reported to be higher than that in normal tissue in many types of human tumors, including colon, breast, prostate, kidney, liver, and brain cancers (Cangul et al., 2002). On the other hand, Cap43 expression is upregulated in normal cells and highly differentiated cancer cells, but downregulated in poorly differentiated cancer cells present in colon and prostate tumors (Bandyopadhyay et al., 2003; Guan et al., 2000). Although the exact function of Cap43 in malignant cells also remains unknown, a variety of studies has recently reported. In prostate cancer, Cap43 could be a novel marker for malignant progression and poor prognosis and is closely associated with the downregulation of E-cadherin expression (Song et al., 2010). In gastric cancer, Cap43 plays a significant role in carcinogenesis and in preventing metastasis and invasion (Jiang et al., 2010; Liu et al., 2010). Further, Cap43 
enhanced portal vein invasion and intrahepatic metastasis in human hepatocellular carcinoma and the Cap 43 expression was thought to accelerate tumor invasion and metastasis (Akiba et al., 2008). In breast cancer, overexpression of the Cap43 gene inhibited cell growth and metastasis, and low Cap43 expression in breast cancer cells is closely correlated with poor clinical outcomes (Bandyopadhyay et al., 2004). These results indicate that one of the roles of Cap43 is suppression of metastasis; further, the Cap43 expression levels could serve as a good predictor of survival in breast cancer. Furthermore, Fotovati et al. (2011) reported that the endogenous Cap43 expression level was closely correlated with the differentiation status of breast cancer cell lines and that Cap43 overexpression expanded the differentiated areas in the xenograft model of breast cancer. Immunohistochemical analysis of human breast cancer specimens showed a close relationship between Cap43 and beta-casein or milk fat protein, which is a differentiation marker of breast tissue. Therefore, Cap43 is closely associated with the differentiation and/or malignant states of breast cancers. As reported in previous studies, the Cap43 gene could play a key role in breast cancer. Therefore, in order to assess the potential of Cap43 as a molecular target for the effects of anti-estrogenic agents in breast cancer, we investigated Cap43 gene expression during therapeutic treatment with anti-estrogenic drugs. Of the 8 breast cancer cell lines we examined, 4 expressed high levels of Cap43 and very low levels of estrogen receptor alpha $\square$ (ER alpha) and the remaining 4 expressed low levels of Cap43 and high ER alpha levels. Estradiol $\left(\mathrm{E}_{2}\right)$ treatment reduced Cap43 expression in a dose-dependent fashion in ER alpha-positive cell lines, but did not affect the expression in ER alpha-negative lines. Administration of the 2 anti-estrogenic agents tamoxifen and ICI 182780 inhibited the $\mathrm{E}_{2}-$ induced downregulation of Cap43. Overexpression of ER alpha in the ER alpha-negative cell lines SKBR-3 and MDA-MB-231 resulted in the downregulation of Cap43. Immunostaining revealed that Cap43 expression was inversely correlated with the expression of ER alpha. The $E_{2}$-induced downregulation of Cap43 appears to be mediated through ER alphadependent pathways in breast cancer cells, both in culture and in patients (Fotovati et al., 2006). Since Cap43 expression was very sensitive to $E_{2}$ and/or anti-estrogens in ER alphapositive breast cancer cells, it is a potential molecular marker for determining the therapeutic efficacy of anti-estrogenic agents in breast cancer. In breast cancer therapy, when ER alpha(+) Cap43(-) patients are treated with tamoxifen, resulting in upregulation of Cap43, tamoxifen appears to be effective and the treatment should be continued. However, if Cap43 is not upregulated following tamoxifen administration in ER alpha(+) Cap43(-) patients, tamoxifen can be deemed ineffective, and the treatment should be changed. The postoperative blood Cap43 level can be easily measured; however, Cap43 is not a secreted protein. This poses clinical problems; to overcome these, we are currently exploring proteins that might be associated with Cap43. If the protein associated with Cap43 is identified, the Cap43 levels can be indirectly obtained by measuring the levels of this protein. Further studies are required in order to use Cap43 in clinical trials.

\section{YB-1}

YB-1 belongs to the cold shock domain protein family, members of which are found in both the cytoplasm and nucleus of human cells. It has pleiotropic functions in the regulation of gene transcription and translation, DNA repair, drug resistance, and cellular responses to 
environmental stimuli (Izumi et al., 2001; Kohno et al., 2003; Kuwano et al., 2003). YB-1 is normally present in the cytoplasm, although it is translocated to the nucleus when cells are exposed to anticancer drugs or ultraviolet (UV) light (Koike et al., 1997; Uchiumi et al., 1993). Nuclear localization of YB-1 is required for its transcriptional control of multidrug resistance (MDR)-related genes and for the control of repair of DNA damage caused by anticancer agents or radiation in cancer cells, resulting in the acquisition of global drug resistance to a wide range of anticancer agents (Kohno et al., 2003; Kuwano et al., 2004). Nuclear translocation of YB-1 is controlled by PKC and related proteins, protein tyrosine phosphatase, JAK1, and Akt (Basaki et al., 2007; Dooley et al., 2006; Koike et al., 1997; Sorokin et al., 2005; Stenina et al., 2000; Sutherland et al., 2005). Immunohistochemical labeling experiments have revealed that nuclear YB-1 expression was correlated with the expression of a representative MDR-related ATP-binding cassette superfamily protein, Pglycoprotein, which is encoded by the MDR1/ABCB1 gene; moreover, other drug resistance-related molecules have been reported in tumor specimens from a variety of cancers other than breast cancer (Bargou et al., 1997; Giménez-Bonafé et al., 2004; Janz et al., 2002; Kamura et al., 1999; Oda et al., 1998; Saji et al., 2003). In contrast, nuclear expression of YB-1 is often associated with a poor prognosis in various human malignancies, including breast cancer (Bargou et al., 1997; Dahl et al., 2009; Janz et al., 2002), ovarian cancer (Kamura et al., 1999), synovial sarcoma (Oda et al., 2003), and lung cancer (Shibahara et al., 2001). These findings strongly suggested that the nuclear expression of YB-1 can be used as a predictor in some human malignancies. Furthermore, the YB-1 gene was able to induce breast cancer in experimental animal models, suggesting its role as an oncogene that promotes the breast cancer progression (Bergmann et al., 2005). Additionally, YB-1 overexpression in human mammary epithelial cells can induce an EGF-independent growth phenotype through activation of the EGFR pathway (Berquin et al., 2005). Knockdown of YB-1 inhibited breast cancer cell growth and it is thought to be involved in the induction of apoptosis via the mTOR/STAT3 intracellular signaling pathway (Fujii et al. 2009, Lee et al., 2008). These studies all suggest a close linkage between YB-1 expression and the growth or proliferation potential of cancer cells via intracellular signaling, and indicate its association with poor prognosis of patients with breast cancer. Since YB-1 might play its key role not only by controlling the expression of drug resistance-related genes but also the expression of cell growth-related genes, we investigated the association of YB-1 localization to the nucleus with the expression of EGFR family proteins, hormone receptors, and other molecules whose expressions are probably associated with poor prognosis in patients with breast cancer. Knockdown of YB-1 with siRNA significantly reduced the expression levels of EGFR, HER2, and ER alpha in ER alpha-positive but not ER alpha-negative breast cancer cell lines. Nuclear YB-1 expression was positively correlated with HER2 $(\mathrm{P}=0.0153)$ and negatively correlated with ER alpha $(\mathrm{P}=0.0122)$ and chemokine (C-X-C motif) receptor 4 (CXCR4: which is known to play a critical role in the growth and metastasis of human breast cancers(Müller A et al., 2001, Liang, $\mathrm{Z}$ et al., 2004)) ( $\mathrm{P}=0$ 0.0166) in human breast cancer clinical specimens; however, it was not correlated with EGFR expression. Nuclear YB-1 expression was an independent prognostic factor for the overall $(P=0.0139)$ and progression-free $(P=0.0280)$ survival in these patients. These data strongly suggested that nuclear YB-1 localization could be a molecular target of intrinsic importance in not only the acquisition of multidrug resistance but also tumor growth dependent on HER2 and other growth factor receptors in breast cancer (Fujii et al., 2008). Intracellular signaling via Cap43 and YB-1 is illustrated in Fig. 3. 


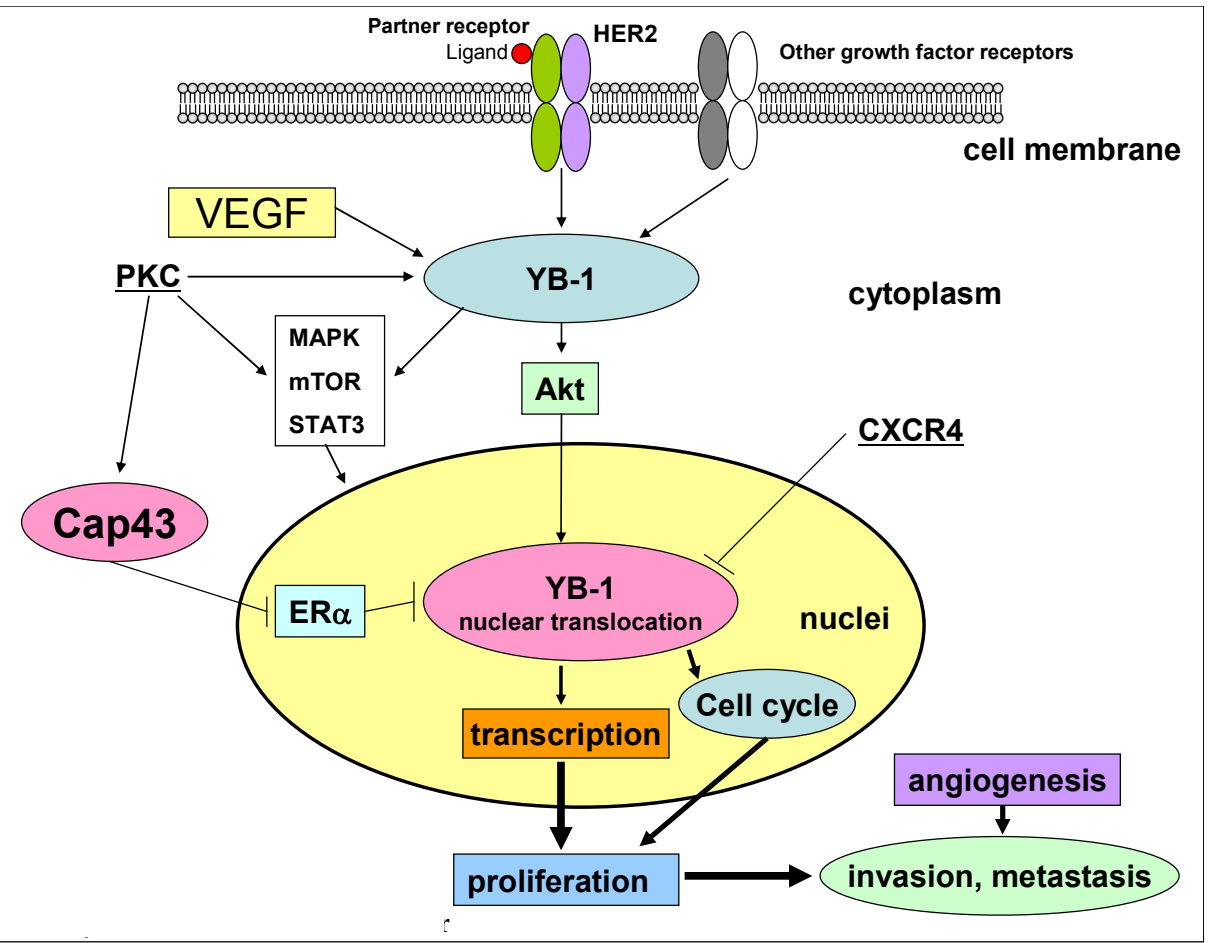

Fig. 3. Intracellular signaling via Cap43 and YB-1 in breast cancer

\section{Conclusion}

The development of effective adjuvant therapy, based on the post-operative administration of chemotherapy, hormone therapy, or trastuzumab, has significantly improved survival among breast cancer patients. However, therapy for adjuvant-resistant or metastatic disease is still palliative, and the possibility of inducing complete remission or a definitive cure for breast cancer remains remote. The research effort so far has identified key selective changes in molecules such as Cap43 and YB-1 that sustain breast cancer growth and progression. This provides the potential to develop specific, targeted therapies as the next generation of anticancer therapeutics.

\section{References}

Adams, CW., Allison, DE., Flagella, K., Presta, L., Clarke, J., Dybdal, N., McKeever, K. \& Sliwkowski, MX. (2006) Humanization of a recombinant monoclonal antibody to produce a therapeutic HER dimerization inhibitor, pertuzumab. Cancer Immunol Immunother, Vol.55, No.6, pp. 717-727.

Akiba, J., Ogasawara, S., Kawahara, A., Nishida, N., Sanada, S., Moriya, F., Kuwano, M., Nakashima, O. \& Yano H. (2008) N-myc downstream regulated gene 1 
(NDRG1)/Cap43 enhances portal vein invasion and intrahepatic metastasis in human hepatocellular carcinoma. Oncol Rep, Vol.20, No.6, pp.1329-1335.

Albanell, J., Rojo, F., Averbuch, S., Feyereislova, A., Mascaro, JM., Herbst, R., LoRusso, P., Rischin, D., Sauleda, S., Gee, J., Nicholson, RI. \& Baselga, J. (2002) Pharmacodynamic studies of the epidermal growth factor receptor inhibitor ZD1839 in skin from cancer patients: histopathologic and molecular consequences of receptor inhibition. J Clin Oncol, Vol.20, No.1, pp. 110-124.

Atalay, G., Cardoso, F., Awada, A. \& Piccart, MJ. (2003) Novel therapeutic strategies targeting the epidermal growth factor receptor (EGFR) family and its downstream effectors in breast cancer. Ann Oncol, Vol.14, No.9, pp. 1346-1363.

Arteaga, CL., O'Neill, A., Moulder, SL., Pins, M., Sparano, JA., Sledge, GW. \& Davidson NE. (2008) A phase I-II study of combined blockade of the ErbB receptor network with trastuzumab and gefitinib in patients with HER2 (ErbB2)-overexpressing metastatic breast cancer. Clin Cancer Res, Vol.14, No.19, pp. 6277-6283.

Bandyopadhyay, S., Pai, SK., Gross, SC., Hirota, S., Hosobe, S., Miura, K., Saito, K., Commes, T., Hayashi, S., Watabe, M. \& Watabe, K. (2003) The Drg-1 gene suppresses tumor metastasis in prostate cancer. Cancer Res, Vol.63, No.8, pp.1731-1736.

Bandyopadhyay, S., Pai, SK., Hirota, S., Hosobe, S., Takano, Y., Saito, K., Piquemal, D., Commes, T., Watabe, M., Gross, SC., Wang, Y., Ran, S. \& Watabe, K. (2004) Role of the putative tumor metastasis suppressor gene Drg-1 in breast cancer progression. Oncogene, Vol.23, No.33, pp.5675-5681.

Bargou, RC., Jürchott, K., Wagener, C., Bergmann, S., Metzner, S., Bommert, K., Mapara, M.Y., Winzer, KJ., Dietel, M., Dörken, B. \& Royer, HD. (1997) Nuclear localization and increased levels of transcription factor YB-1 in primary human breast cancers are associated with intrinsic MDR1 gene expression. Nat Med, Vol.3, No.4, pp.447450.

Basaki, Y., Hosoi, F., Oda, Y., Fotovati, A., Maruyama, Y., Oie, S., Ono, M., Izumi, H., Kohno. K., Sakai, K., Shimoyama, T., Nishio, K. \& Kuwano, M. (2007) Akt-dependent nuclear localization of Y-box-binding protein 1 in acquisition of malignant characteristics by human ovarian cancer cells. Oncogene, Vol.26, No.19, pp.27362746.

Baselga, J., Gelmon, KA., Verma, S., Wardley, A., Conte, P., Miles, D., Bianchi, G., Cortes, J., McNally, VA., Ross, GA., Fumoleau, P. \& Gianni, L. (2010a) Phase II trial of pertuzumab and trastuzumab in patients with human epidermal growth factor receptor 2-positive metastatic breast cancer that progressed during prior trastuzumab therapy. J Clin Oncol, Vol.28, No.7, pp. 1138-1144.

Baselga, J., Bradbury, I., Eidtmann, H., Di Cosimo, S., Aura, C., Azambuja, E., Gomez, H., Dinh, P., Fauria, K., Van Dooren, V., Paoletti, P., Goldhirsch, A., Chang, T-W., Lang, I., Untch, M., Gelber, RD. \& Piccart-Gebhart M. (2010b) First results of the NeoALTTO trial (BIG 01-06/EGF 106903): A phase III, randomized, open label, neoadjuvant study of lapatinib, trastuzumab, and their combination plus paclitaxel in woman with HER2-positive primary breast cancer. Cancer Res, Vol.70, No.24, pp. 82s. (abstract S3-3).

Bell, DW., Lynch, TJ., Haserlat, SM., Harris, PL., Okimoto, RA., Brannigan, BW., Sgroi, DC., Muir, B., Riemenschneider, MJ., Iacona, RB., Krebs, AD., Johnson, DH., Giaccone, G., Herbst, RS., Manegold, C., Fukuoka, M., Kris, MG., Baselga, J., Ochs, JS. \& 
Haber, DA. (2005) Epidermal growth factor receptor mutations and gene amplification in non-small-cell lung cancer: molecular analysis of the IDEAL/INTACT gefitinib trials. J Clin Oncol, Vol.23, No.31, pp.8081-8092.

Bergmann, S., Royer-Pokora, B., Fietze, E., Jürchott, K., Hildebrandt, B., Trost, D., Leenders, F., Claude, J.C., Theuring, F., Bargou, R., Dietel, M. \& Royer, H.D. (2005) YB-1 provokes breast cancer through the induction of chromosomal instability that emerges from mitotic failure and centrosome amplification. Cancer Res, Vol.65, No.10, pp.4078-4087.

Berquin, IM., Pang, B., Dziubinski, ML., Scott, LM., Chen. YQ., Nolan, GP. \& Ethier, SP. (2005) Y-box-binding protein 1 confers EGF independence to human mammary epithelial cells. Oncogene, Vol.24, No.19, pp.3177-3186.

Blackwell, KL., Burstein, HJ., Storniolo, AM., Rugo, H., Sledge, G., Koehler, M., Ellis, C., Casey, M., Vukelja, S., Bischoff, J., Baselga, J. \& O'Shaughnessy, J. (2010) Randomized study of Lapatinib alone or in combination with trastuzumab in women with ErbB2-positive, trastuzumab-refractory metastatic breast cancer. J Clin Oncol, Vol.28, No.7, pp. 1124-1130.

Britten, CD., Finn, RS., Bosserman, LD., Wong, SG., Press, MF., Malik, M., Lum, BL. \& Slamon DJ. (2009) A phase I/II trial of trastuzumab plus erlotinib in metastatic HER2-positive breast cancer: a dual ErbB targeted approach. Clin Breast Cancer, Vol.9, No.1, 16-22.

Burris, HA 3rd., Rugo, HS., Vukelja, SJ., Vogel, CL., Borson, RA., Limentani, S., Tan-Chiu, E., Krop, IE., Michaelson, RA., Girish, S., Amler, L., Zheng, M., Chu, YW., Klencke, B. \& O'Shaughnessy JA. (2011) Phase II study of the antibody drug conjugate trastuzumab-DM1 for the treatment of human epidermal growth factor receptor 2 (HER2)-positive breast cancer after prior HER2-directed therapy. J Clin Oncol, Vol.29, No.4, pp. 398-405.

Campiglio, M., Locatelli, A., Olgiati, C., Normanno, N., Somenzi, G., Viganò, L., Fumagalli, M., Ménard, S. \& Gianni, L. J. (2004) Inhibition of proliferation and induction of apoptosis in breast cancer cells by the epidermal growth factor receptor (EGFR) tyrosine kinase inhibitor ZD1839 ('Iressa') is independent of EGFR expression level.Cell Physiol., Vol.198, No.2, pp. 259-268.

Cangul, H.; Salnikow, K.; Yee, H.; Zagzag, D.; Commes, T.; Costa, M. Enhanced expression of a novel protein in human cancer cells: a potential aid to cancer diagnosis. Cell Biol Toxicol, Vol.18, No.2, pp.87-96.

Ciardiello, F., Caputo, R., Bianco, R., Damiano, V., Pomatico, G., De Placido, S., Bianco, A.R. \& Tortora, G. (2000) Antitumor effect and potentiation of cytotoxic drugs activity in human cancer cells by ZD-1839 (Iressa), an epidermal growth factor receptorselective tyrosine kinase inhibitor. Clin Cancer Res, Vol.6, No.5, 2053-2063.

ClinicalTrials.gov 1. A study of a combination of trastuzumab and capecitabine with or without pertuzumab in patients with HER2-positive metastatic breast cancer (PHEREXA). Available from

http:/ / clinicaltrials.gov/ct2/show/NCT01026142?term=pertuzumab+breast+canc er\&rank $=7$.

ClinicalTrials.gov 2. Erlotinib and Everolimus in treating patients with metastatic breast cancer. Available from 
http:/ / clinicaltrials.gov/ct2/show/NCT00574366?term=erlotinib+breast+cancer\&r ank=3.

ClinicalTrials.gov 3. Randomized, double blind multicenter phase II study of time to progression on fulvestrant in combination with erlotinib or placebo in hormone receptor-positive metastatic breast cancer (MBC) subjects who progressed on first line hormonal therapy. Available from

http:/ / clinicaltrials.gov/ct2/show/NCT00570258?term=erlotinib+breast+cancer\&r ank $=18$.

ClinicalTrials.gov 4. Erlotinib plus docetaxel in treating patients with stage IV or recurrent breast cancer. Available from

http://clinicaltrials.gov/ct2/show/NCT00054275?term=erlotinib+breast+cancer\&r ank $=8$.

Clinicaltrials.gov 5. Phase II trial of doxil, carboplatin, bevacizumab in triple negative untreated metastatic breast cancer. Available from

http:/ / clinicaltrials.gov/ct2/show/NCT00608972?term=bevacizumab+AND+meta static+breast+cancer\&rank $=1$.

Clinicaltrials.gov 6. Weekly paclitaxel/carboplatin/ bevacizumab as first line therapy for triple negative breast cancer. Available from

http:/ / clinicaltrials.gov/ct2/show/NCT00691379?term=bevacizumab+AND+meta static+breast+cancer\&rank $=63$.

Cobleigh, MA., Langmuir, VK., Sledge, GW., Miller, KD., Haney, L., Novotny, WF., Reimann, JD. \& Vassel, A. (2003) A phase I/II dose-escalation trial of bevacizumab in previously treated metastatic breast cancer. Semin Oncol, Vol.30, (5 Suppl 16), pp.117-124.

Cortes, J., Baselga, J., Petrella, T., Gelmon, K., Fumoleau, P., Verma, S., Pivot, X., Ross, G., Szado, T. \& Gianni L. (2009) Pertuzumab monotherapy following trastuzumabbased treatment: activity and tolerability in patients with advanced HER2 positive breast cancer. J Clin Oncol, Vol. pp.46s. (abstract 1022).

Cristofanilli, M., Valero, V., Mangalik, A., Royce, M., Rabinowitz, I., Arena, FP., Kroener, JF., Curcio, E., Watkins, C., Bacus, S., Cora, EM., Anderson, E. \& Magill, PJ. (2010) Phase II, randomized trial to compare anastrozole combined with gefitinib or placebo in postmenopausal women with hormone receptor-positive metastatic breast cancer. Clin Cancer Res, Vol.16, No.6, pp. 1904-1914.

Dahl, E., En-Nia, A., Wiesmann, F., Krings, R., Djudjaj, S., Breuer, E., Fuchs, T., Wild, PJ., Hartmann, A., Dunn, SE. \& Mertens, PR. (2009) Nuclear detection of Y-box protein1 (YB-1) closely associates with progesterone receptor negativity and is a strong adverse survival factor in human breast cancer. BMC Cancer, Vol.9, pp.410.

Dennison, SK., Jacobs, SA., Wilson, JW., Seeger, J., Cescon, TP., Raymond, JM., Geyer, CE., Wolmark, N. \& Swain, SM. (2007) A phase II clinical trial of ZD1839 (Iressa) in combination with docetaxel as first-line treatment in patients with advanced breast cancer. Invest New Drugs, Vol.25, No.6, pp. 545-551.

Dickler, MN., Rugo, HS., Eberle, CA., Brogi, E., Caravelli, JF., Panageas, KS., Boyd, J., Yeh, B., Lake, DE., Dang, CT., Gilewski, TA., Bromberg, JF., Seidman, AD., D'Andrea, GM., Moasser, MM., Melisko, M., Park, JW., Dancey, J., Norton, L. \& Hudis CA. (2008) A phase II trial of erlotinib in combination with bevacizumab in patients with metastatic breast cancer. Clin Cancer Res, Vol.14, No.23, pp. 7878-7883. 
Dickler, MN., Cobleigh, MA., Miller, KD., Klein, PM. \& Winer, EP. (2009) Efficacy and safety of erlotinib in patients with locally advanced or metastatic breast cancer. Breast Cancer Res Treat, Vol.115, No.1, 115-121.

Di Leo, A., Gomez, HL., Aziz, Z., Zvirbule, Z., Bines, J., Arbushites, MC., Guerrera, SF., Koehler, M., Oliv, C., Stein, SH., Williams, LS., Dering, J., Finn, RS. \& Press MF. (2008) Phase III, double-blind, randomized study comparing lapatinib plus paclitaxel with placebo plus paclitaxel as first-line treatment for metastatic breast cancer. J Clin Oncol, Vol.26, No.34, pp. 5544-5552.

Dooley, S., Said, HM., Gressner, AM., Floege, J., En-Nia, A. \& Mertens, PR. (2006) Y-box protein-1 is the crucial mediator of antifibrotic interferon-gamma effects. J Biol Chem, Vol.281, No.3, pp.1784-1795.

Ellard, SL., Clemons, M., Gelmon, KA., Norris, B., Kennecke, H., Chia, S., Pritchard, K., Eisen, A., Vandenberg, T., Taylor, M., Sauerbrei, E., Mishaeli, M., Huntsman, D., Walsh, W., Olivo, M., McIntosh, L. \& Seymour L. (2009) Randomized phase II study comparing two schedules of everolimus in patients with recurrent/metastatic breast cancer: NCIC Clinical Trials Group IND.163. J Clin Oncol, Vol.27, No.27, pp.4536-4541.

Ferrara, N., Gerber, HP. \& LeCouter, J. (2003) The biology of VEGF and its receptors. Nat Med, Vol.9, No.6, pp.669-676.

Finn RS, Wilson CA, Sanders J et al. Targeting the epidermal growth factor receptor and HER-2 with OSI-774 and trastuzumab, respectively, in HER-2 overexpressing human breast cancer cell lines in a therapeutic advantage in vitro. Proc Am Soc Clin Oncol 2003; 22. 235 (Abstract 940)

Fotovati, A., Fujii, T., Yamaguchi, M., Kage, M., Shirouzu, K., Oie, S., Basaki, Y., Ono, M., Yamana, H. \& Kuwano M. (2006) $17 \beta$-estradiol induces down-regulation of Cap43/NDRG1/Drg-1, a putative differentiation-related and metastasis suppressor gene, in human breast cancer cells. Clin Cancer Res, Vol.12, No.10, pp.3010-3018.

Fotovati, A., Abu-Ali, S., Kage, M., Shirouzu, K., Yamana, H. \& Kuwano M. (2011) N-myc Downstream-regulated Gene 1 (NDRG1) a Differentiation Marker of Human Breast Cancer. Pathol Oncol Res, (Epub ahead of print).

Fox, SB., Generali, DG. \& Harris AL. (2007) Breast tumour angiogenesis. Breast Cancer Res, Vol.9, No.6, pp.216.

Fox, WD., Higgins, B., Maiese, KM., Drobnjak, M., Cordon-Cardo, C., Scher, HI. \& Agus, DB. (2002) Antibody to vascular endothelial growth factor slows growth of an androgen-independent xenograft model of prostate cancer. Clin Cancer Res, Vol.8, No.10, pp.3226-3231.

Franklin, MC., Carey, KD., Vajdos, FF., Leahy, DJ., de Vos, AM. \& Sliwkowski, MX. (2004) Insights into ErbB signaling from the structure of the ErbB2-pertuzumab complex. Cancer Cell, Vol.5, No.4, pp. 317-328.

Fujii, T., Kawahara, A., Basaki, Y., Hattori, S., Nakashima, K., Nakano, K., Shirouzu, K., Kohno, K., Yanagawa, T., Yamana, H., Nishio, K., Ono, M., Kuwano, M. \& Kage, M. (2008) Expression of HER2 and estrogen receptor alpha depends upon nuclear localization of Y-box binding protein-1 in human breast cancers. Cancer Res, Vol.68, No.5, pp.1504-1512. 
Fujii, T., Seki, N., Namoto-Matsubayashi, R., Takahashi, H., Inoue, Y., Toh, U., Kage, M. \& Shirouzu, K. (2009) YB-1 prevents apoptosis via the mTOR/STAT3 pathway in HER-2-overexpressing breast cancer cells. Future Oncol, Vol.5, No.2, pp.153-156.

Fukuoka, M., Yano, S., Giaccone, G., Tamura, T., Nakagawa, K,., Douillard, JY., Nishiwaki, Y., Vansteenkiste, J., Kudoh, S., Rischin, D., Eek, R., Horai, T., Noda, K., Takata, I., Smit, E., Averbuch, S., Macleod, A., Feyereislova, A., Dong, RP. \& Baselga, J. (2003) Multi-institutional randomized phase II trial of gefitinib for previously treated patients with advanced non-small-cell lung cancer (The IDEAL 1 Trial) J Clin Oncol, Vol.21, No.12, pp.2237-2246.

Geyer, CE., Forster, J., Lindquist, D., Chan, S., Romieu, CG., Pienkowski, T., JagielloGruszfeld, A., Crown, J., Chan, A., Kaufman, B., Skarlos, D., Campone, M., Davidson, N., Berger, M., Oliva, C., Rubin, S.D., Stein, S. \& Cameron, D. (2006) Lapatinib plus capecitabine for HER2-positive advanced breast cancer. $N$ Engl J Med, 2006, Vol.355, No.26, pp. 2733-2743.

Gianni, L., Eiermann, W., Semiglazov, V., Manikhas, A., Lluch, A., Tjulandin, S., Zambetti, M., Vazquez, F., Byakhow, M., Lichinitser, M., Climent, MA., Ciruelos, E., Ojeda, B., Mansutti, M., Bozhok, A., Baronio, R., Feyereislova, A., Barton, C., Valagussa, P. \& Baselga, J. (2010a) Neoadjuvant chemotherapy with trastuzumab followed by adjuvant trastuzumab versus neoadjuvant chemotherapy alone, in patients with HER2-positive locally advanced breast cancer (the NOAH trial): a randomised controlled superiority trial with a parallel HER2-negative cohort. Lancet, Vol.375, No.9712, pp. 377-384.

Gianni, L., Lladó, A., Bianchi, G., Cortes, J., Kellokumpu-Lehtinen, PL., Cameron, DA., Miles, D., Salvagni, S., Wardley, A., Goeminne, JC., Hersberger, V. \& Baselga, J. (2010b) Open-label, phase II, multicenter, randomized study of the efficacy and safety of two dose levels of Pertuzumab, a human epidermal growth factor receptor 2 dimerization inhibitor, in patients with human epidermal growth factor receptor 2-negative metastatic breast cancer. J Clin Oncol, Vol.28, No.7, pp. 1131-1137.

Gianni, L., Pienkowski, T., Im, Y-H., Roman, L., Tseng, L-M., Liu, M-C., Lluch-Hernandez, A., Semiglazov, V., Szado, T. \& Ross, G. (2010c) Neoadjuvant pertuzumab (P) and trastuzumab (T): Antitumor and safety analysis of a randomized phase II study ('NeoSphere'). Cancer Res, Vol.70, No.24, pp. 82s (abstract S3-2).

Giménez-Bonafé, P., Fedoruk, MN., Whitmore, TG., Akbari, M., Ralph, JL., Ettinger, S., Gleave, ME. \& Nelson, CC. (2004) YB-1 is upregulated during prostate cancer tumor progression and increases P-glycoprotein activity. Prostate, Vol.59, No.3, pp.337-349.

Goldhirsch, A., Ingle, JN., Gelber, RD., Coates, AS., Thürlimann, B. \& Senn, HJ; Panel members. (2009) Thresholds for therapies: highlights of the St Gallen International Expert Consensus on the primary therapy of early breast cancer 2009. Ann Oncol, Vol.20, No.8, pp. 1319-1329.

Gomez, HL., Doval, DC., Chavez, MA., Ang, PC., Aziz, Z., Nag, S., Ng, C., Franco, SX., Chow, LW., Arbushites, MC., Casey, MA., Berger, MS., Stein, SH. \& Sledge, GW. (2008) Efficacy and safety of lapatinib as first-line therapy for ErbB2-amplified locally advanced or metastatic breast cancer. J Clin Oncol, Vol.26, No.18, pp. 29993005. 
Gonzalez-Angulo, AM., Litton, JK., Broglio, KR., Meric-Bernstam, F., Rakkhit, R., Cardoso, F., Peintinger, F., Hanrahan, EO., Sahin, A., Guray, M., Larsimont, D., Feoli, F., Stranzl, H., Buchholz, TA., Valero, V., Theriault, R., Piccart-Gebhart, M., Ravdin, PM., Berry, DA. \& Hortobagyi, GN. (2009) High risk of recurrence for patients with breast cancer who have human epidermal growth factor receptor 2-positive, nodenegative tumors $1 \mathrm{~cm}$ or smaller. J Clin Oncol, Vol.27, No.34, pp. 5700-5706.

Gril, B., Palmieri, D., Bronder, JL., Herring, JM., Vega-Valle, E., Feigenbaum, L., Liewehr, DJ., Steinberg, SM., Merino, MJ., Rubin, SD. \& Steeg PS. (2008) Effect of lapatinib on the outgrowth of metastatic breast cancer cells to the brain. J Natl Cancer Inst, Vol.100, No.15, 1092-1103.

Guan, RJ., Ford, HL., Fu, Y., Li, Y., Shaw, LM. \& Pardee, AB. (2000) Drg-1 as a differentiation-related, putative metastatic suppressor gene in human colon cancer. Cancer Res, Vol.60, No.3, pp. 749-755.

Hubbard, SR. (2005) EGF receptor inhibition: attacks on multiple fronts. Cancer Cell, Vol.7, No.4, pp. 287-288.

Izumi, H., Imamura, T., Nagatani, G., Ise, T., Murakami, T., Uramoto, H., Torigoe, T., Ishiguchi, H., Yoshida, Y., Nomoto, M., Okamoto, T., Uchiumi, T., Kuwano, M., Funa, K. \& Kohno. K. (2001) Y box-binding protein-1 binds preferentially to singlestranded nucleic acids and exhibits 3'-->5' exonuclease activity. Nucleic Acids Res, Vol.29, No.5, pp.1200-1207.

Jain, RK. (2003) Molecular regulation of vessel maturation. Nat Med, Vol.9, No.6, pp.685-693.

Janz, M., Harbeck, N., Dettmar, P., Berger, U., Schmidt, A., Jürchott, K., Schmitt, M. \& Royer HD. (2002) Y-box factor YB-1 predicts drug resistance and patient outcome in breast cancer independent of clinically relevant tumor biologic factors HER2, uPA and PAI-1. Int J Cancer, Vol.97, No.3, pp.278-282.

Jerusalem, G., Fasolo, A., Dieras, V., Cardoso, F., Bergh, J., Vittori, L., Zhang, Y., Massacesi, C., Sahmoud, T. \& Gianni L. (2011) Phase I trial of oral mTOR inhibitor everolimus in combination with trastuzumab and vinorelbine in pre-treated patients with HER2-overexpressing metastatic breast cancer. Breast Cancer Res Treat, Vol.125, No.2, pp.447-455.

Jiang, K., Shen, Z., Ye, Y., Yang, X. \& Wang S. (2010) A novel molecular marker for early detection and evaluating prognosis of gastric cancer: $\mathrm{N}$-myc downstream regulated gene-1 (NDRG1). Scand J Gastroenterol. Vol.45, No.7-8, pp.898-908.

Joensuu, H., Kellokumpu-Lehtinen, PL., Bono, P., Alanko, T., Kataja, V., Asola, R., Utriainen, T., Kokko, R., Hemminki, A., Tarkkanen, M., Turpeenniemi-Hujanen, T., Jyrkkiö, S., Flander, M., Helle, L., Ingalsuo, S., Johansson, K., Jääskeläinen, AS., Pajunen, M., Rauhala, M., Kaleva-Kerola, J., Salminen, T., Leinonen, M., Elomaa, I., Isola, J.; FinHer Study Investigators. (2006) Adjuvant docetaxel or vinorelbine with or without trastuzumab for breast cancer. N Engl J Med, Vol.354, No.8, pp. 809-820.

Jung, YD., Mansfield, PF., Akagi, M., Takeda, A., Liu, W., Bucana, CD., Hicklin, DJ. \& Ellis, LM. (2002) Effects of combination anti-vascular endothelial growth factor receptor and anti-epidermal growth factor receptor therapies on the growth of gastric cancer in a nude mouse model. Eur J Cancer, Vol.38, No.8, pp. 1133-1140.

Kamura, T., Yahata, H., Amada, S., Ogawa, S., Sonoda, T., Kobayashi, H., Mitsumoto, M., Kohno, K., Kuwano, M. \& Nakano, H. (1999) Is nuclear expression of Y box-binding 
protein-1 a new prognostic factor in ovarian serous adenocarcinoma? Cancer, Vol.85, No.11, pp.2450-2454.

Kim, KJ., Li, B., Winer, J., Armanini, M., Gillett, N., Phillips, HS. \& Ferrara N. (1993) Inhibition of vascular endothelial growth factor-induced angiogenesis suppresses tumour growth in vivo. Nature, Vol.362, No.6423, pp.841-844.

Klos, KS., Wyszomierski, SL., Sun, M., Tan, M., Zhou, X., Li, P., Yang, W., Yin, G., Hittelman, WN. \& Yu, D. (2006) ErbB2 increases vascular endothelial growth factor protein synthesis via activation of mammalian target of rapamycin/p70S6K leading to increased angiogenesis and spontaneous metastasis of human breast cancer cells. Cancer Res, Vol.66, No.4, pp.2028-2037.

Kohno, K., Izumi, H., Uchiumi, T., Ashizuka, M. \& Kuwano. M. (2003) The pleiotropic functions of the Y-box-binding protein, YB-1. Bioessays, Vol.25, No.7, pp.691-698.

Koike, K., Uchiumi, T., Ohga, T., Toh, S., Wada, M., Kohno, K. \& Kuwano, M. (1997) Nuclear translocation of the Y-box binding protein by ultraviolet irradiation. FEBS Lett, Vol. 417, No.3, pp.390-394.

Konecny, GE., Meng, YG., Untch, M., Wang, HJ., Bauerfeind, I., Epstein, M., Stieber, P., Vernes, JM., Gutierrez, J., Hong, K., Beryt, M., Hepp, H., Slamon, DJ. \& Pegram, MD. (2004) Association between HER-2/neu and vascular endothelial growth factor expression predicts clinical outcome in primary breast cancer patients. Clin Cancer Res, Vol.10, No.5, pp.1706-1716.

Konecny, GE., Pegram, MD., Venkatesan, N., Finn, R., Yang, G., Rahmeh, M., Untch, M., Rusnak, DW., Spehar, G., Mullin, RJ., Keith, BR., Gilmer, TM., Berger, M., Podratz, KC. \& Slamon, DJ. (2006) Activity of the dual kinase inhibitor lapatinib (GW572016) against HER-2-overexpressing and trastuzumab-treated breast cancer cells. Cancer Res, Vol.66, No.3, pp. 1630-1639.

Koutras, AK., Fountzilas, G., Kalogeras, KT., Starakis, I., Iconomou, G. \& Kalofonos, HP. (2010) The upgraded role of HER3 and HER4 receptors in breast cancer. Crit Rev Oncol Hematol, Vol.74, No.2, pp. 73-78.

Kuwano, M., Uchiumi, T., Hayakawa, H., Ono, M., Wada, M., Izumi, H. \& Kohno. K. (2003) The basic and clinical implications of $\mathrm{ABC}$ transporters, Y-box-binding protein-1 (YB-1) and angiogenesis-related factors in human malignancies. Cancer Sci, Vol.94, No.1, pp9-14.

Kuwano, M., Oda, Y., Izumi, H., Yang, SJ., Uchiumi, T., Iwamoto, Y., Toi, M., Fujii, T., Yamana, H., Kinoshita, H., Kamura, T., Tsuneyoshi, M., Yasumoto, K. \& Kohno K. (2004) The role of nuclear Y-box binding protein 1 as a global marker in drug resistance. Mol Cancer Ther, Vol.3, No.11, pp.1485-1492.

Lachat, P., Shaw, P., Gebhard, S., van Belzen, N., Chaubert, P. \& Bosman, FT. (2002) Expression of NDRG1, a differentiation-related gene, in human tissues. Histochem Cell Biol, Vol.118, No.5, pp.399-408.

Lackey, KE. (2006) Lessons from the drug discovery of lapatinib, a dual ErbB1/2 tyrosine kinase inhibitor. Curr Top Med Chem, Vol.6, No.5, pp. 435-460.

Lee, C., Dhillon, J., Wang, MY., Gao, Y., Hu, K., Park, E., Astanehe, A., Hung, MC., Eirew, P., Eaves, CJ. \& Dunn SE. (2008) Targeting YB-1 in HER-2 overexpressing breast cancer cells induces apoptosis via the mTOR/STAT3 pathway and suppresses tumor growth in mice. Cancer Res, Vol.68, No.21, pp.8661-8666. 
Lee, SY., Kim, DK., Cho, JH., Koh, JY. \& Yoon YH. (2008) Inhibitory effect of bevacizumab on the angiogenesis and growth of retinoblastoma. Arch Ophthalmol, Vol.126, No.7, pp.953-958.

Liang, Z., Wu, T., Lou, H., Yu, X., Taichman, RS., Lau, SK., Nie, S., Umbreit, J., Shim, H. (2004) Inhibition of breast cancer metastasis by selective synthetic polypeptide against CXCR4. Cancer Res, Vol.64, No.12, 4302-4308.

Lin, NU. \& Winer, EP. (2004) New targets for therapy in breast cancer: small molecule tyrosine kinase inhibitors. Breast Cancer Res, Vol.6, No.5, pp. 204-210.

Lin, NU., Diéras, V., Paul, D., Lossignol, D., Christodoulou, C., Stemmler, HJ., Roché, H., Liu, MC., Greil, R., Ciruelos, E., Loibl, S., Gori, S., Wardley, A., Yardley, D., Brufsky, A., Blum, JL., Rubin, SD., Dharan, B., Steplewski, K., Zembryki, D., Oliva, C., Roychowdhury, D., Paoletti, P. \& Winer EP. (2009) Multicenter phase II study of lapatinib in patients with brain metastases from HER2-positive breast cancer. Clin Cancer Res, Vol.15, No.4, 1452-1459.

Liu, YL., Bai, WT., Luo, W., Zhang, DX., Yan, Y., Xu, ZK. \& Zhang FL. (2011) Downregulation of NDRG1 promotes invasion of human gastric cancer AGS cells through MMP-2. Tumour Biol, Vol.32, No.1, pp.99-105.

Lu, C., Speers, C., Zhang, Y., Xu, X., Hill, J., Steinbis, E., Celestino, J., Shen, Q. Kim, H., Hilsenbeck, S., Mohsin, SK., Wakeling, A., Osborne, CK. \& Brown, PH. (2003) Effect of epidermal growth factor receptor inhibitor on development of estrogen receptornegative mammary tumors. J Natl Cancer Inst, Vol.95, No.24, pp. 1825-1833.

Lu, CH., Wyszomierski, SL., Tseng, LM., Sun, MH., Lan, KH., Neal, CL., Mills, GB., Hortobagyi, GN., Esteva, FJ. \& Yu D. (2007) Preclinical testing of clinically applicable strategies for overcoming trastuzumab resistance caused by PTEN deficiency. Clin Cancer Res, Vol.13, No.19, pp.5883-5888.

McArthur, HL., Mahoney, K., Morris, PG., Patil, S., Jacks, LM., Howard, J., Norton, L. \& Hudis, C. (2010) Use of adjuvant trastuzumab with chemotherapy in women with small, node-negative, HER2-positive breast cancers. J Clin Oncol, Vol.28, pp 95s. (abstract 615).

Metro, G., Foglietta, J., Stocchi, L., Russillo, M., Papaldo, P., Crino, L., Giannarelli, D., Cognetti, F., Fabi, A. \& Gori, S. (2010) Outcome of patients(pts) with brain metasitases (BMs) from HER2-positive breast cancer (BC) treated with lapatinib plus capecitabine (LC). J Clin Oncol, Vol.28, pp.152s, (abstract 1155)

Miles D et al. (2009) Final overall survival (OS) results from the randomized, double-blind, phase III AVADO study of bevacizumab (BEV) plus docetaxel (DOC) compared with placebo plus DOC for the first-line treatment of locally recurrent or metastatic breast cancer. San Antonio Breast Cancer Symposium (abstract 41)

Miller, K., Wang, M., Gralow, J., Dickler, M., Cobleigh, M., Perez, EA., Shenkier, T., Cella, D. \& Davidson NE. (2007) Paclitaxel plus bevacizumab versus paclitaxel alone for metastatic breast cancer. N Engl J Med, Vol.357, No.26, pp.2666-2676.

Miller, K., Gianni, L., Andre, F., Dieras, V., Mahtani, RL., Harbeck, N., Huang, JE., Shih, T., Choi, Y. \& Burris, HA III. (2010) A phase Ib/II trial of trastuzumab-DM1 (T-DM1) with pertuzumab (P) for women with HER2-positive, locally advanced or metastatic breast cancer (BC) who were previously treated with trastuzumab (T). J Clin Oncol, Vol.28, No15S, pp. 117s. (abstract 1012). 
Moulder, SL., Yakes, FM., Muthuswamy, SK., Bianco, R., Simpson, JF. \& Arteaga, C.L. (2001) Epidermal growth factor receptor (HER1) tyrosine kinase inhibitor ZD1839 (Iressa) inhibits HER2/neu (erbB2)-overexpressing breast cancer cells in vitro and in vivo. Cancer Res, Vol. 61, No.24, pp. 8887-8895.

Moyer, JD., Barbacci, EG., Iwata, KK., Arnold, L., Boman, B., Cunningham, A., DiOrio, C., Doty, J., Morin, MJ., Moyer, MP., Neveu, M., Pollack, VA., Pustilnik, LR., Reynolds, MM., Sloan, D., Theleman, A.\& Miller, P. (1997) Induction of apoptosis and cell cycle arrest by CP-358,774, an inhibitor of epidermal growth factor receptor tyrosine kinase. Cancer Res, Vol.57, No.21, pp. 4838-4848.

Müller, A., Homey, B., Soto, H., Ge, N., Catron, D., Buchanan, ME., McClanahan, T., Murphy, E., Yuan, W., Wagner, SN., Barrera, JL., Mohar, A., Verástegui, E., Zlotnik, A. (2001) Involvement of chemokine receptors in breast cancer metastasis. Nature, Vol.410, No.6824, pp. 50-56.

NCCN Clinical Practice Guidelines in Oncology ${ }^{\mathrm{TM}}$ Breast Cancer Version 1. 2011 available from http://www.nccn.com.

Normanno, N., Campiglio, M., De, LA., Somenzi, G., Maiello, M., Ciardiello, F., Gianni, L., Salomon, DS. \& Menard, S. (2002) Cooperative inhibitory effect of ZD1839 (Iressa) in combination with trastuzumab (Herceptin) on human breast cancer cell growth. Ann Oncol, Vol.13, No.1, pp.65-72.

Oda, Y., Sakamoto, A., Shinohara, N., Ohga, T., Uchiumi, T., Kohno, K., Tsuneyoshi, M., Kuwano, M. \& Iwamoto, Y. (1998) Nuclear expression of YB-1 protein correlates with P-glycoprotein expression in human osteosarcoma. Clin Cancer Res, Vol.4, No.9, pp.2273-2277.

Oda, Y., Ohishi, Y., Saito, T., Hinoshita, E., Uchiumi, T., Kinukawa, N., Iwamoto, Y., Kohno, K., Kuwano, M. \& Tsuneyoshi, M. (2003) Nuclear expression of Y-box-binding protein-1 correlates with P-glycoprotein and topoisomerase II alpha expression, and with poor prognosis in synovial sarcoma. J Pathol, Vol.199, No.2, pp.251-258.

Okuda. H., Hirai, S., Takaki, Y., Kamada, M., Baba, M., Sakai, N., Kishida, T., Kaneko, S., Yao, M., Ohno, S. \& Shuin, T. (1999) Direct interaction of the beta-domain of VHL tumor suppressor protein with the regulatory domain of atypical PKC isotypes. Biochem Biophys Res Commun, Vol.263, No.2, pp.491-497.

Osborne, CK., Neven, P., Dirix, LY., Mackey, JR., Robert, J., Underhill, C., Schiff, R., Gutierrez, C., Migliaccio, I., Anagnostou, VK., Rimm, DL., Magill, P. \& Sellers M. (2011) Gefitinib or placebo in combination with tamoxifen in patients with hormone receptor-positive metastatic breast cancer: A randomized phase II study. Clin Cancer Res, Vol.17, No.5, 1147-1159.

O'Shaughnessy, JA. \& Brufsky AM. (2008) RiBBON 1 and RiBBON 2: phase III trials of bevacizumab with standard chemotherapy for metastatic breast cancer. Clin Breast Cancer, Vol.8, No.4, pp.370-373.

Pegram, M., Chan, D., Dichmann, RA., et al. (2006) Phase II combined biological therapy targeting the HER2 proto-oncogene and the vascular endothelial growth factor using trastuzumab (T) and bevacizumab (B) as first line treatment of HER2amplified breast cancer. Breast Cancer Res Treat. Vol.100, S28, (Abstract 301).

Perez, EA., Romond, EH., Suman, VJ., Jeong, J., Davidson, NE., Geyer, CE., Martino, S., Mamounas, EP., Kauffman, PA., \& Wolmark, N. (2007) Updated results of the combined analysis of NCCTG N9831 and NSABP B-31 adjuvant chemotherapy 
with/without trastuzumab in patients with HER2-positive breast cancer. J Clin Oncol, Vol.25, pp. 6s. (abstract 512).

Pérez-Soler, R., Chachoua, A., Hammond, LA., Rowinsky, EK., Huberman, M., Karp, D., Rigas, J., Clark, GM., Santabárbara, P. \& Bonomi, P. (2004) Determinants of tumor response and survival with erlotinib in patients with non--small-cell lung cancer. J Clin Oncol, Vol.22, No.16, pp. 3238-3247.

Pollack, VA., Savage, DM., Baker, DA., Tsaparikos, KE., Sloan, DE., Moyer, JD., Barbacci, E.G., Pustilnik, LR., Smolarek, TA., Davis, JA., Vaidya, MP., Arnold, LD., Doty, JL., Iwata, KK. \& Morin, MJ. (1999) Inhibition of epidermal growth factor receptorassociated tyrosine phosphorylation in human carcinomas with CP-358,774: dynamics of receptor inhibition in situ and antitumor effects in athymic mice. $J$ Pharmacol Exp Ther, Vol.291, No.2, 739-748.

Ro, J., Park, S., Kim, T-Y., Im, Y-H., Rha, SY., Chung, JS., Moon, H. \& Santillana S. (2010) Clinical outcomes of brain metastasis by lapatinib (L) and capecitabine (C) in an open-label expanded access study among Korean patients with HER2 positive metastatic breast cancer. Cancer Res, Vol.70, No.24, (abstract P1-14-04).

Rosen, LS., Ashurst, HL. \& Chap, L. (2010) Targeting signal transduction pathways in metastatic breast cancer: a comprehensive review. Oncologist, Vol.15, No.3, pp. 216235.

Russo, SM. \& Ove, R. (2003) Molecular targets as therapeutic strategies in the management of breast cancer. Expert Opin Ther Targets, Vol.7, No.4, pp. 543-557.

Saji, H., Toi, M., Saji, S., Koike, M., Kohno, K. \& Kuwano, M. (2003) Nuclear expression of YB-1 protein correlates with P-glycoprotein expression in human breast carcinoma. Cancer Lett, Vol.190, No.2, pp.191-197.

Segerström, L., Fuchs, D., Bäckman, U., Holmquist, K., Christofferson, R. \& Azarbayjani F. (2006) The anti-VEGF antibody bevacizumab potently reduces the growth rate of high-risk neuroblastoma xenografts. Pediatr Res, Vol.60, No.5, pp.576-581.

Scheuer, W., Friess, T. \& Hasmann, M. (2006) Enhanced antitumour effect by combination of HER2-targeting antibodies with bevacizumab in a human breast cancer xenograft model. Eur J Cancer, Suppl4, pp.66 (Abstract 213).

Scheuer, W., Friess, T., Burtscher, H., Bossenmaier, B., Endl, J. \& Hasmann, M. (2009) Strongly enhanced antitumor activity of trastuzumab and pertuzumab combination treatment on HER2-positive human xenograft tumor models. Cancer Res, Vol.69, No.24, pp. 9330-9336.

Schlotter, CM., Vogt, U., Allgayer, H. \& Brandt, B. (2008) Molecular targeted therapies for breast cancer treatment. Breast Cancer Res, Vol.10, No.4, pp.211.

Shibahara, K., Sugio, K., Osaki, T., Uchiumi, T., Maehara, Y., Kohno, K., Yasumoto, K., Sugimachi, K. \& Kuwano, M. (2001) Nuclear expression of the Y-box binding protein, YB-1, as a novel marker of disease progression in non-small cell lung cancer. Clin Cancer Res, Vol. 7, No.10, pp.3151-3155.

Shibuya M. (2001) Structure and function of VEGF/VEGF-receptor system involved in angiogenesis. Cell Struct Funct, Vol.26, No.1, pp.25-35.

Shimono, A., Okuda, T. \& Kondoh, H. (1999) N-myc-dependent repression of ndr1, a gene identified by direct subtraction of whole mouse embryo cDNAs between wild type and N-myc mutant. Mech Dev, Vol.83, No.1-2, pp.39-52. 
Sirotnak, FM., Zakowski, MF., Miller, VA., Scher, HI. \& Kris, MG. (2000) Efficacy of cytotoxic agents against human tumor xenografts is markedly enhanced by coadministration of ZD1839 (Iressa), an inhibitor of EGFR tyrosine kinase. Clin Cancer Res, Vol.6, No.12, 4885-4892.

Slamon, DJ., Leyland-Jones, B., Shak, S., Fuchs, H., Paton, V., Bajamonde, A., Fleming, T., Eiermann, W., Wolter, J., Pegram, M., Baselga, J. \& Norton L. (2001) Use of chemotherapy plus a monoclonal antibody against HER2 for metastatic breast cancer that overexpresses HER2. N Engl J Med, Vol.344, No.11, pp. 783-792.

Slamon D, Eiermann W, Robert N, et al. (2006) BCIRG 006: 2nd interim analysis phase III randomized trial comparing doxorubicin and cyclophosphamide followed by docetaxel (AC->T) with doxorubicin and cyclophosphamide followed by docetaxel and trastuzumab (AC-> TH) with docetaxel, carboplatin and trastuzumab (TCH) in Her2neu positive early breast cancer patients. Breast Cancer Res Treat 100(Suppl 1)(abstract 52).

Smith, I., Procter, M., Gelber, RD., Guillaume, S., Feyereislova, A., Dowsett, M., Goldhirsch, A., Untch, M., Mariani, G., Baselga, J., Kaufmann, M., Cameron, D., Bell, R., Bergh, J., Coleman, R., Wardley, A., Harbeck, N., Lopez, RI., Mallmann, P., Gelmon, K., Wilcken, N., Wist, E., Sánchez Rovira, P. \& Piccart-Gebhart, MJ.; HERA study team. (2007) 2-year follow-up of trastuzumab after adjuvant chemotherapy in HER2positive breast cancer: a randomised controlled trial. Lancet, Vol.369, No.9555, pp. 29-36.

Song, Y., Oda, Y., Hori, M., Kuroiwa, K., Ono, M., Hosoi, F., Basaki, Y., Tokunaga, S., Kuwano, M., Naito, S. \& Tsuneyoshi M. (2010) N-myc downstream regulated gene$1 /$ Cap43 may play an important role in malignant progression of prostate cancer, in its close association with E-cadherin. Hum Pathol, Vol.41, No.2, pp.214-222.

Sørlie T, Perou CM, Tibshirani R, Aas T, Geisler S, Johnsen H, Hastie T, Eisen MB, van de Rijn M, Jeffrey SS, Thorsen T, Quist H, Matese JC, Brown PO, Botstein D, Eystein Lønning P, Børresen-Dale AL. (2001) Gene expression patterns of breast carcinomas distinguish tumor subclasses with clinical implications. Proc Natl Acad Sci U S A, Vol.98, No.19, pp.10869-10874.

Sorokin, AV., Selyutina, AA., Skabkin, MA., Guryanov, SG., Nazimov, IV., Richard, C., Th'ng, J., Yau, J., Sorensen, PH., Ovchinnikov, LP. \& Evdokimova, V. (2005) Proteasome-mediated cleavage of the Y-box-binding protein 1 is linked to DNAdamage stress response. EMBO J, Vol.24, No.20, pp.3602-3612.

Soulieres, D., Senzer, NN., Vokes, EE., Hidalgo, M., Agarwala, SS. \& Siu, LL. (2004) Multicenter phase II study of erlotinib, an oral epidermal growth factor receptor tyrosine kinase inhibitor, in patients with recurrent or metastatic squamous cell cancer of the head and neck. J Clin Oncol, Vol.22, No.1, pp. 77-85.

Stenina, OI., Poptic, EJ. \& DiCorleto, PE. (2000) Thrombin activates a Y box-binding protein (DNA-binding protein B) in endothelial cells. J Clin Invest, Vol.106, No.4, pp.579587.

Sutherland, BW., Kucab, J., Wu, J., Lee, C., Cheang, MC., Yorida, E., Turbin, D., Dedhar, S., Nelson, C., Pollak, M., Leighton Grimes, H., Miller, K., Badve, S., Huntsman, D. Blake-Gilks, C., Chen, M., Pallen, CJ. \& Dunn, SE. (2005) Akt phosphorylates the Ybox binding protein 1 at Ser102 located in the cold shock domain and affects the 
anchorage-independent growth of breast cancer cells. Oncogene, Vo.24, No.26, pp.4281-4292.

Takahashi, T., Ueno, H. \& Shibuya, M. (1999) VEGF activates protein kinase C-dependent, but Ras-independent Raf-MEK-MAP kinase pathway for DNA synthesis in primary endothelial cells. Oncogene, Vol.18, No.13, pp.2221-2230.

Thomas, MB., Chadha, R., Glover, K., Wang, X., Morris, J., Brown, T., Rashid, A., Dancey, J. \& Abbruzzese, JL. (2007) Phase 2 study of erlotinib in patients with unresectable hepatocellular carcinoma. Cancer, Vol.110, No.5, pp. 1059-1067.

Uchiumi, T.; Kohno, K.; Tanimura, H.; Matsuo, K.; Sato, S.; Uchida, Y.; Kuwano. M. (1993) Enhanced expression of the human multidrug resistance 1 gene in response to UV light irradiation. Cell Growth Differ, Vol.4, No.3, pp147-157.

Vogel, CL., Cobleigh, MA., Tripathy, D., Gutheil, JC., Harris, LN., Fehrenbacher, L., Slamon, DJ., Murphy, M., Novotny, WF., Burchmore, M., Shak, S., Stewart, SJ. \& Press, M. (2002) Efficacy and safety of trastuzumab as a single agent in first-line treatment of HER2-overexpressing metastatic breast cancer. J Clin Oncol, Vol.20, No.3, pp. 719726.

Vogel, C., Chan, A., Gril, B., Kim, SB., Kurebayashi, J., Liu, L., Lu, YS. \& Moon, H. (2010) Management of ErbB2-positive breast cancer: insights from preclinical and clinical studies with lapatinib. Jpn J Clin Oncol, Vol.40, No.11, pp. 999-1013.

von Minckwitz, G., Jonat, W., Fasching, P., du Bois, A., Kleeberg, U., Lück, H.J., Kettner, E., Hilfrich, J., Eiermann, W., Torode, J. \& Schneeweiss, A. (2005) A multicentre phase II study on gefitinib in taxane- and anthracycline-pretreated metastatic breast cancer. Breast Cancer Res Treat, Vol.89, No.2, pp. 165-172.

Wakeling, AE., Guy, SP., Woodburn, JR., Ashton, SE., Curry, BJ., Barker, AJ. \& Gibson, KH. (2002) ZD1839 (Iressa): an orally active inhibitor of epidermal growth factor signaling with potential for cancer therapy. Cancer Res, Vol.62, No.20, pp. 57495754.

Wakisaka, Y., Furuta, A., Masuda, K., Morikawa, W., Kuwano, M. \& Iwaki, T. (2003) Cellular distribution of NDRG1 protein in the rat kidney and brain during normal postnatal development. J Histochem Cytochem, Vol.51, No.11, pp.1515-1525.

Witton, CJ., Reeves, JR., Going, JJ., Cooke, TG. \& Bartlett, JM. (2003) Expression of the HER14 family of receptor tyrosine kinases in breast cancer. J Pathol, Vol.200, No.3, pp. 290-297.

Woodburn, J.R. (1999) The epidermal growth factor receptor and its inhibition in cancer therapy. Pharmacol Ther, Vol.82,No.2-3, pp. 241-250.

Xia, W., Mullin, RJ., Keith, BR., Liu, LH., Ma, H., Rusnak, DW., Owens, G., Alligood, KJ. \& Spector, NL. (2002) Anti-tumor activity of GW572016: a dual tyrosine kinase inhibitor blocks EGF activation of EGFR/erbB2 and downstream Erk1/2 and AKT pathways. Oncogene, Vol.21, No.41, pp. 6255-6263.

Xia, W., Gerard, CM., Liu, L., Baudson, NM., Ory, TL. \& Spector, NL. (2005) Combining lapatinib (GW572016), a small molecule inhibitor of ErbB1 and ErbB2 tyrosine kinases, with therapeutic anti-ErbB2 antibodies enhances apoptosis of ErbB2overexpressing breast cancer cells.Oncogene, Vol.24, No.41, pp. 6213-6221.

Yancopoulos, GD., Davis, S., Gale, NW., Rudge, JS., Wiegand, SJ. \& Holash, J. (2000) Vascular-specific growth factors and blood vessel formation. Nature, Vol.407, No.6801, pp.242-248. 


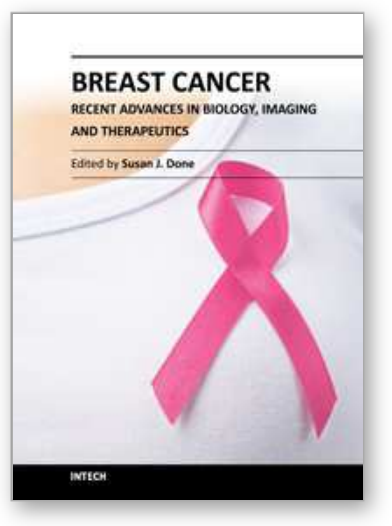

\section{Breast Cancer - Recent Advances in Biology, Imaging and Therapeutics}

Edited by Dr. Susan Done

ISBN 978-953-307-730-7

Hard cover, 428 pages

Publisher InTech

Published online 14, December, 2011

Published in print edition December, 2011

In recent years it has become clear that breast cancer is not a single disease but rather that the term encompasses a number of molecularly distinct tumors arising from the epithelial cells of the breast. There is an urgent need to better understand these distinct subtypes and develop tailored diagnostic approaches and treatments appropriate to each. This book considers breast cancer from many novel and exciting perspectives. New insights into the basic biology of breast cancer are discussed together with high throughput approaches to molecular profiling. Innovative strategies for diagnosis and imaging are presented as well as emerging perspectives on breast cancer treatment. Each of the topics in this volume is addressed by respected experts in their fields and it is hoped that readers will be stimulated and challenged by the contents.

\section{How to reference}

In order to correctly reference this scholarly work, feel free to copy and paste the following:

Teruhiko Fujii, Hiroki Takahashi, Yuka Inoue, Masayoshi Kage, Hideaki Yamana and Kazuo Shirouzu (2011). Preclinical and Clinical Developments in Molecular Targeting Therapeutic Strategies for Breast Cancer, Breast Cancer - Recent Advances in Biology, Imaging and Therapeutics, Dr. Susan Done (Ed.), ISBN: 978-953-307730-7, InTech, Available from: http://www.intechopen.com/books/breast-cancer-recent-advances-in-biologyimaging-and-therapeutics/preclinical-and-clinical-developments-in-molecular-targeting-therapeutic-strategiesfor-breast-cance

\section{INTECH}

open science | open minds

\section{InTech Europe}

University Campus STeP Ri

Slavka Krautzeka 83/A

51000 Rijeka, Croatia

Phone: +385 (51) 770447

Fax: +385 (51) 686166

www.intechopen.com

\section{InTech China}

Unit 405, Office Block, Hotel Equatorial Shanghai

No.65, Yan An Road (West), Shanghai, 200040, China

中国上海市延安西路65号上海国际贵都大饭店办公楼 405 单元

Phone: +86-21-62489820

Fax: $+86-21-62489821$ 
(C) 2011 The Author(s). Licensee IntechOpen. This is an open access article distributed under the terms of the Creative Commons Attribution 3.0 License, which permits unrestricted use, distribution, and reproduction in any medium, provided the original work is properly cited. 